\title{
Entre el exceso y el castigo Una lectura económica del mito de Edipo ${ }^{1}$
}

Comentario a "¿Por qué Edipo?" (Christopher Bollas, en Ser un personaje. Psicoanálisis y experiencia del sí-mismo. Buenos Aires: Amorrortu, 1994. [Original de 1992])

\section{Realizado por Miguel Huertas ${ }^{2}$}

Edipo sigue siendo un mito cuyo análisis es de indudable interés, tanto por sus características particulares como por pertenecer a los ciclos mitológicos que fundamentan nuestra cultura.

Es por ello por lo que creo que, como sucede en ciertas obras de arte, puede aplicarse el psicoanálisis al mito, pero también el mito al psicoanálisis, si tenemos en cuenta que la mitología es una suerte de psicología de la antigüedad y que ambas se iluminan mutuamente (Hillman, 2004). Esta óptica puede conectarse también con lo expuesto por Bollas (1994).

El mito de Edipo ha servido como base de la teorización freudiana original y tampoco está exento de una lectura más afín al marco relacional en el que nos movemos. El protagonista de la tragedia comienza su historia abandonado por sus padres biológicos, con el pie mutilado que le daría nombre haciendo las veces de la marca del trauma que es quizá menos evidente para la mayoría de personas que han sufrido un déficit temprano importante, pero que de igual modo puede evidenciarse tanto en síntomas -en el sentido quizá más clásico del término- en patrones de relación disfuncionales y cíclicos que hacen las veces de tejido cicatrizal de la psique. Y en esa línea podemos leer también las posiciones de Killingmo (1989) acerca de las patologías de conflicto y de déficit (o "principalmente" de conflicto y "principalmente" de déficit) y también la afirmación de que cierta disociación se encuentra en la base de toda personalidad (Bromberg, 2017).

En el flujo del mito recogido por Sófocles encontramos también la tragedia familiar y cómo la patología fluye por la trama conformada por el grupo primario, cuando conocemos que la Esfinge, es un castigo a los actos de Layo, quien cometió, como cometerá posteriormente su hijo, un exceso (hýbris).

\footnotetext{
${ }^{1}$ Huertas, M. (2018). Entre el exceso y el castigo. Una lectura económica del mito de Edipo. Clínica e Investigación Relacional, 12 (2): 393-396. [ISSN 1988-2939] [Recuperado de www.ceir.info ] DOI: 10.21110/19882939.2018.120212

${ }^{2}$ Miembro del Instituto de Psicoterapia Relacional.

CelR Vol. 12 (2) - Junio 2018 ISSN 1988-2939 - www.ceir.info

(c) Derechos reservados/Copyright de Clínica e investigación Relacional y los autores. Prohibida la reproducción total o parcial sin autorización expresa. Este material es para uso científico y profesional exclusivamente y puede contener información clínica sensible. Los editores no se responsabilizan de los contenidos de los autores. Dirigir las consultas sobre derechos y autorizaciones a ceir@psicoterapiarelacional.es
} 
Siguiendo a Marinas (2004), la Esfinge griega es una criatura singular precisamente por su naturaleza híbrida: con aspectos de mujer, águila, y serpiente, es un ser liminar. Sus rasgos pueden remitirnos a lo originario, mientras que sus atributos depredadores nos hablan de la capacidad para extinguir la vida. Agudizando este carácter múltiple encontramos que surge de una genealogía monstruosa que une la herencia de la tierra, del mar, y del inframundo. Es tebana, pero acecha siempre fuera de sus murallas, presentando su enigma a quienes tratan de entrar en la ciudad. En sí misma la Esfinge es frontera hecha carne, una habitante del umbral, y por tanto un interrogante: ella misma es la pregunta.

Me parece de interés tener en cuenta la relación que guarda la naturaleza del exceso con la naturaleza del castigo divino que, con un cierto giro de tuerca, podría llevarnos a hablar de una cierta "dimensión económica del mito".

Si revisamos el origen y las consecuencias de los hýbris de Edipo y Layo podríamos ver que presentan, en su estructura, un correlato de la formación de síntomas.

Layo (Grimal, 1984, p.310), hijo de Lábdaco, reinó sobre Tebas y trajo sobre sí y sobre su ciudad un terrible castigo al "amar de forma culpable" (Grimal, 1984, p.174) a Crisipo, hijo de Pélope. Este arrebato del rey es de naturaleza claramente pulsional, especialmente por el empuje a la satisfacción inmediata y por encima de cualquier cosa: Layo habría raptado a Crisipo en contra de su voluntad (Grimal, 1984, p.119), quebrando además la hospitalidad de Pélope. Este exceso, que choca contra el muro de la prohibición sagrada, demanda una respuesta. Esta respuesta no es otra que la Esfinge (Grimal, 1984, p.174), un monstruo femenino con rostro de mujer, cuerpo de león, y alas de rapaz, que asfixiaría con sus garras a sus víctimas después de que éstas no diesen con las respuestas a sus acertijos.

Podemos ver cómo el castigo por los excesos y las desmesuras de Layo en la persona de Crisipo guarda una estrecha relación con el mismo crimen cometido. La Esfinge es un monstruo cuyo carácter es claramente punitivo y es, por tanto, hija de la prohibición. Pero, ¿es hija también de los actos de Layo? Después de todo, es monstruo humano, al tener rostro y cabeza de persona, y a esto se le une una ferocidad depredadora. Una persona presa de un apetito monstruoso, el cual le lleva a apresar a sus víctimas en un abrazo violento. ¿Y, no fue un "abrazo violento" lo que sufrió Crisipo tras ser raptado por Layo? Como vemos, la Esfinge es hija de los apetitos despiadados de Layo y de la prohibición que rompen, permitiéndonos sugerir que existe un correlato estructural entre ambos relatos, uno mítico, otro psicoanalítico.

¿Qué ocurre con Edipo? A diferencia de su padre, él es ciego -o quizá se ciega (Bollas, 1994)a su exceso. 
A diferencia de Layo, Edipo ignora sus excesos. A modo de profecía autocumplida, pretendiendo evitar los crímenes que un oráculo le ha vaticinado, acaba cometiéndolos: en una encrucijada abate a su padre biológico y a parte de su séquito, y después, tras haberse librado de la Esfinge, es nombrado Rey de Tebas y se desposa con su madre Yocasta sin advertir la relación que los une. Su crimen, por lo tanto, es doble: no sólo derrama la sangre que le dio la vida, sino que transciende los límites de lo humano cometiendo un incesto reservado a los dioses. La respuesta a esta quiebra del orden natural es una horrible plaga que cae con fuerza sobre la ciudad de Tebas:

"La población perece en número incontable. Sus hijos, abandonados, yacen en el suelo, portadores de muerte, sin obtener ninguna compasión. Entretanto, esposas y, también, canosas madres gimen por doquier en las gradas de los templos, en actitud de suplicantes, a causa de sus tristes desgracias. Resuena el peán y se oye, al mismo tiempo, un sonido de lamentos(...)" (Sófocles, 2009).

La plaga surge como respuesta a los actos de Edipo; es por lo tanto, hija de la prohibición. Sin embargo, y atendiendo al relato mítico recogido por Sófocles, es también hija de sus excesos de Edipo. El rey tebano actúa en manos de hado como una fuerza ciega, cometiendo los más atroces crímenes sin conciencia alguna de ellos, tropezando con su destino como si el pie herido que le da nombre fuese el culpable de ello. La plaga que asola Tebas aniquila a su gente: hijos, esposas, canosas madres... El castigo cae indistintamente. ¿No es, acaso, una fuerza ciega? Del mismo modo que Edipo cometió sus crímenes de desmesura, el hýbris, ajeno a lo que hacía y sin distinguir la mácula en sus acciones, el castigo por ellos se abate sin distinción entre los habitantes de Tebas.

Como Bollas (1994) da a entender, una parte de Edipo, la voz acallada de un aspecto de su Self, conoce la verdad sobre el asesino de Layo. Pero, si seguimos a lógica de este autor, no es el único que lo sabe: la Esfinge también conoce esta verdad, al indicar a los ciudadanos tebanos que "miren a sus pies". Es mirando hacia abajo donde puede verse el secreto ocultado a plena vista, el pie mutilado de quien fue un niño abandonado. Y es esto también lo que nos permite conectar la Esfinge, castigo del exceso del padre, con el conocimiento del exceso del hijo.

En otro de los mitos fundamentales de nuestra cultura encontramos que "el hijo no llevará el pecado del padre", sin embargo, en este mito ya no se produce una descripción sino un aleccionamiento, un principio de ilusión. Porque si atendemos al funcionamiento de la falta básica, del déficit temprano, del trauma, de la defensa moral, o de la identificación con el agresor, podemos entender que los hijos sí portan los pecados de sus padres, y que, como 
indica otra parte de este mismo ciclo mitológico judeocristiano, la maldad de los padres cae sobre los hijos hasta la tercera o cuarta generación.

\section{REFERENCIAS}

Bollas, C. (1994). Ser un personaje. Psicoanálisis y experiencia del sí-mismo. Buenos Aires, Argentina: Amorrortu. (pp. 265-297).

Bromberg, P. (2017). La sombra del Tsunami y el desarrollo de la mente relacional. Madrid, España: Ágora Relacional.

Grimal, P. (1984). Diccionario de mitología griega y romana. Madrid: Paidós Ibérica.

Hillman, J. (2004). El sueño y el inframundo. Barcelona: Paidós Ibérica.

Killingmo, B. (1989). Conflict and Deficit: Implications for Technique. International Journal of Psychoanalysis, 70:65-79.

Marinas, J. M. (2004). La ciudad y la esfinge. Contexto ético del psicoanálisis. Madrid, España: Síntesis. (pp. 137-152). 